\title{
sciendo
}

\section{Fostering Frontline Employees' Innovative Service Behavior: The Role of Workplace Friendship and Knowledge Sharing Process}

\author{
Irfan HELMY ${ }^{1}$, Wiwiek Rabiatul ADAWIYAH ${ }^{2}$, \\ Harini Abrilia SETYAWATI ${ }^{1}$
}

\begin{abstract}
${ }^{1}$ Putra Bangsa Economics College, Department of Management, Kebumen, Indonesia, risetirfan@gmail.com, harini.abrilia.setyawati@gmail.com
\end{abstract}

${ }^{2}$ Jenderal Soedirman University, Faculty of Economics and Business, Purwokerto, Indonesia, wiwiekra@gmail.com (corresponding author)

Background and purpose: The hospitality industries need to create benevolent work environment and social activities that stimulate frontline service employees (FLEs) innovative behavior. Drawing on social capital theory, this study aims to examine the influence of workplace friendship on promoting FLEs' innovative service behavior. This study also examines the mediating role of knowledge sharing process (knowledge collecting and knowledge donating) on the relationship between workplace friendship and FLEs' innovative service behavior.

Design/Methodology/Approach: For data collection, the convenience sampling method is applied to survey 163 frontline employees in 3- and 4-stars tourist hotels located in Yogyakarta, Indonesia. The present study performed structural equation modelling (PLS-SEM) software Smart-PLS v3.0 to test the hypotheses.

Results: The result showed that workplace friendship has significant influence on FLEs' innovative service behavior. Also, this study empirically found that workplace friendship influence FLEs' innovative service behavior directly and indirectly trough knowledge collecting. Interestingly, knowledge donating has insignificant effect on FLEs innovative service behavior.

Conclusion: We conclude that workplace friendship could create a favorable work environment that fostering FLEs innovative service behavior trough knowledge sharing process. Therefore, this research adds to the body of knowledge by pointing out the influence of workplace friendship and knowledge sharing process on FLEs innovative service behavior. This present study also provides the human resource practice regarding how to nurturing workplace friendship that stimulates FLEs innovative work behavior.

Keywords: Frontline service employees, Innovative service behavior, Workplace friendship, Knowledge collecting, Knowledge donating

\section{Introduction}

Existing literature focuses on the hospitality industry has primarily emphasized the critical role of frontline employees (FLEs) on service performance. Frontline workers interact with the customer personally (Ordanini \& Parasuraman, 2011) and create impressive guest-host interaction, rather than narrowly focusing on routine operational work as a means of building customer experience and loyalty. They have to capture customers' needs and capable of improving products and services innovatively. Innovation is a key competency that helps workers dealing with their unpredictable novel tasks. Medallia Institute surveyed frontline employees of hospitality, retail and financial ser-

Received: 20th March 2020; revised: 27th May 2020; accepted: 28th June 2020 
vices companies in the U.S. The result concluded that $56 \%$ of FLE possessing brilliant ideas that could improve their companies' practices, and $43 \%$ alleged that their insights could reduce costs of service delivery (Benjamin, 2016). The Medallia study punctuated FLEs as a wealth of an organization. The workers dazzling knowledge and intuition may be used as the organizational think-tank to face the fast-paced nature of business competition.

Despite the conventional wisdom, there is an ongoing debate on the importance of fostering innovative behaviors among frontline employees in service settings. The management literature highlights the need for business firms to doggedly foster innovative behaviors among frontline employees, no matter the cost in order to survive the constant state of radical transformation (Santos-Vijande et al. 2016; Engen, \& Magnusson, 2015). Recent studies pinpoint the prominence of nurturing FLEs innovative behavior in service organizations. Leaders should encourage their FLEs to be more innovative (Ozkok et al. 2019; Al-Hawari, Melhem, \& Shamsudin, 2019) to survive the onslaught of business competition.

In the meantime, pieces of literature revealed the factors that might inhibit FLEs' innovative service behavior. Lack of support from the organization and the absence of reward for creative behaviors are among the factors that hinder employees' innovative service behavior (Yeşil \& Hirlak, 2013). Most frontline employees are anxious about risk, and they are reluctant to propose new ideas at work, which slows down the service innovation process (Melton \& Hartline, 2010). Addressing this point, managers should create favorable workplace environments aiming at solving the obstacles and, in turn, encourage FLEs' innovative service behavior.

Past studies have massively explored the antecedents of FLEs' innovative service behavior, such as learning goal orientation (Montani, Odoardi, \& Battistelli, 2014), knowledge sharing (Kim \& Lee, 2013), managerial support (Wynen et al. 2019), leadership (Yidong, \& Xinxin, 2013) and social interaction (Michael, Hou, \& Fan, 2011). In this study, we focus on the relationship between workplace friendship and FLEs innovative service behavior. The focus of the study is motivated, particularly by the fact that the research is still reported inconsistent and inconclusive findings. For instance, Okoe et al. (2018) examined the relationship between human resource practice outcomes and service innovation from across service industries in Ghana. Contrary to previous studies, They found that the interaction of workplace friendship and knowledge sharing had no significant effect on service innovation. Another study, Maria, Jong, \& Zacharias (2017), also stated that support form colleagues weakened the relationship between job engagement and FLEs innovative service behavior in the banking and finance sector. This research gap calls for more studies to reinvestigate the correlation between workplace friendship and FLEs innovative service behavior in different context (Okoe et al., 2018).
Testing the model in wider context shall increase the generalizability of the theory, therefore adds value to the body of knowledge in the field. This research was conducted in tourist hotels located in Indonesia. Data released by the National Bureau of Statistics of Indonesia (BPS) showed a proliferation of occupancy rates of hotels in Indonesia by $4,54 \%$ in 2019 , and approximately $28 \%$ of hotel guests were a foreign tourist. Thus, the following research is necessary to assist professionals in finding the best way to promote FLEs innovative behavior to face the increasing complexity oh hotel guests' demands and to anticipate the uncertain novel duties of their jobs.

Furthermore, in building a relationship between workplace friendship and FLEs' innovative service behavior, this study posits the role of the knowledge sharing process as a mediating variable. The new insight may resolve the inconclusive findings on workplace friendship-innovation relationship observed in the most relevant literatures. This study provides research contributions in several primary ways. First, this study extends prior research on the connection between workplace friendship and FLEs innovative service behavior. Second, by integrating the knowledge sharing process, this study has investigated the underlying process of how workplace friendship leads to FLEs' innovative service behavior via knowledge collecting and knowledge donating. Third, this study extended the generalization of the research model by the context tourist hotel sector in Indonesia. Finally, the findings of this paper can bring attention to the tourist hotel's management in the case of nurturing the friendly work environment that increasing FLEs innovative service behavior.

\section{Literature Review}

\subsection{Innovative Service Behavior}

Innovative behavior is a form of individual engagement in the innovation process, including initiative and application of an idea, product, or procedure (Scot \& Bruce, 1994). Previous studies agreed that innovation is different from creativity; even some research are often used the terms interchangeably (Farr \& Ford, 1990; Scot \& Bruce, 1994). Creativity is a process of creating an idea, while innovative subsequent provided an idea until an implementation or application process. Accordingly, creativity is a component of innovation. Based on their seminal work, Scot \& Bruce (1994) stated that innovative behavior is viewed as a multi-stage process that is starting from problem recognition, generating an idea or solution, and seek a coalition to support the idea. Finally, the last stage is completing the concept by producing the model or product of innovation. De Jong \& Hartog (2010) developed four distinctive stages of innovative behavior, namely idea exploration, idea-generating, idea championing, and idea implementation. First 
stage, idea exploration includes looking for ways to improve current products, services, or processes. Idea generation is the stage where individuals use their creativity to create something new and beneficial to the progress of an organization or company. Idea promotion is the stage of finding and gathering partners, sponsors, or supporters of ideas that have been generated. Moreover, the last stage after idea promotion is idea realization, which includes implementing or realizing ideas in the work environment. This study explored the effect of workplace friendship on innovative service behavior. According to Wang \& Hou (2015), individual innovative behavior strongly depends on their quality network relationship (e.g., friendship) at the workplace because this kind of relationship provided the necessary information, resources, and support which help an employee to promote and realize their new ideas.

\subsection{Workplace Friendship, Knowledge Sharing Process and Innovative Service Behavior}

Sias \& Cahill (1998) have a focus on developing a friendship relationship in the workplace. They found that increasing frequent and intimate interaction in the workplace shall foster workplace friendship. Berman, West, \& Richter (2002) defined workplace friendship as a non-exclusive relationship at work that involves mutual trust, commitment, reciprocal liking, and shared interest and values. Morrison (2004) also mentioned that workplace friendship colored by voluntary, reciprocal, and equality relationships. Recently, Pillemer \& Rothbard (2018) explained four distinctive characteristics of workplace friendship, namely informality, voluntary, socio-emotional, communal norms. The first element, voluntary and informality, means that friendship among co-workers is not formally initiated by the organization, and there is a lack of standard (non-hierarchical) in the relationship (Berman, West, \& Richter, 2002; Sias et al. 2004). Second, workplace friendship is characterized by the communal norm and social support. The main goal of relationship is to provide support among friends and foster affective and relational wellbeing (Morrison \& Cooper-Thomas, 2016). Previous researches have acknowledge several benefits of workplace friendships, such as reduced stress, turnover intention, and increased job satisfaction and organizational commitment (Morrison, 2004). Further, workplace friendship has improved performance (Hsu et al. 2016; Berman, West, \& Richter, 2002) and job involvement (Riordan \& Griffeth, 1995). However, several studies also pointed out the negative outcomes of friendship at work. For instance, negative gossip, instrumental goal conflict, decreased loyalty, low productivity, and negative politic in the organization (Song \& Olshfski, 2008; Pillemer \& Rothbard, 2018). But overall, friendship has a beneficial effect on individuals and organizations (Zarankin \& Kunkel, 2019). In their study Kratzer,
Leenders \& Engelen (2006) assert that human interaction in the organization was the critical antecedent to innovation. It means that employees' innovativeness depends on collaboration among employees (Gottfridsson, 2014). Besides, workplace friendship, as a social collectiveness, motivates employees to share ideas and method in order to solve problems or to generate new products (Faraj \& Wasko, 2001). Thus, we proposed the following hypothesis:

H1: Workplace friendship has a significant influence on FLEs' innovative service behavior.

H2: Workplace friendship has a significant influence on knowledge collecting.

H3: Workplace friendship has a significant influence on knowledge donating.

\subsection{Mediating Role of Knowledge Sharing Process}

Knowledge sharing is defined as a process where individuals mutually exchange tacit or explicit knowledge to create new knowledge (Van Den Hooff \& De Ridder's, 2004). However, conceptually, terminology of knowledge sharing is often interchangeable with the concept of knowledge transfer and knowledge exchange (Zheng, 2017). Several studies have provided clear limitations about the differences between knowledge sharing and knowledge transfer in the knowledge management literature (Tangaraja et al., 2016). Knowledge sharing is a series of actions carried out by an individual (people to people process) within an organization member while knowledge transfer is used primarily to describe the movement of knowledge between larger entities in the organization, such as between departments or divisions or organizations themselves. On the other hand, knowledge exchange is an individual activity within organizations that do knowledge sharing and knowledge-seeking (individuals who seek knowledge from their colleagues) (Paulin \& Suneson, 2015).

In this current study, social capital theory was employed in linking workplace friendship, knowledge sharing process, and innovative service behavior. The concept of social capital explains the organizational resources that arose from the interaction between members, involving knowledge exchange or knowledge management activities (Nahapiet \& Ghoshal, 1998, p. 243). Recent knowledge management literature has considered social capital as the main instrument that facilitates knowledge sharing and innovation in the organization. For instance, Weerakoon et al. (2019) investigated the linkage between links between social capital, opportunity-motivation-abilities, knowledge creation, and innovativeness within $R \& D$ teams in Iran. They found that strength of the ties among the organizational members leads to knowledge creation, and significantly promoted innovativeness. Another study, Akhavan \& Hosseini (2015), indicated that social capital was asso- 
ciated with knowledge sharing behavior that, in turn, was significantly related to innovation capability. Past studies has recognized interpersonal trust as the critical component of workplace friendship that motivate employee to participate in knowledge sharing activity (Sias et al. 2004; Wu et al. 2009). In this view, this present study analyzed the role of workplace friendship as the form of social capital on delivering knowledge sharing process and innovative work behavior in organization.

Knowledge management literature showed that the knowledge sharing process involve both efforts of bringing and getting knowledge. Ardichvili, Page \& Wentling (2003) noted that knowledge sharing consists of "knowledge supply" and "knowledge demand" while Oldenkamp (2001) divided knowledge sharing process into "knowledge carrier" and "knowledge requester". Another study by Van Den Hooff and De Ridder's, (2004: 118) proposed knowledge sharing process as "knowledge donating" and "knowledge collecting" activity. Knowledge donating is an activity of communicating intellectual capital to other colleagues, while knowledge collecting is about strengthening colleagues so they can persuade them to share their intellectual capital.

This study investigates the role of knowledge collecting and knowledge donating as mediating variables between workplace friendship and FLEs innovative service behavior. The nomological validity of the model was based on the previous research model addressing the antecedents and consequences of innovative service behavior (Tierney \& Farmer, 2002). Akram et al. (2018) mentioned that these two forms of knowledge sharing have their own individual standing and effects in the literature. For instance, Kim \& Lee (2013) examined the effects of goal orientation on innovative service behavior with knowledge sharing as the mediator in a survey on 418 FLEs hotel in Korea. They found the positive association between learning goal orientation and innovative service behavior via knowledge sharing process. In addition, the study indicated that knowledge collecting is a more reliable predictor of innovative service behavior. Another study, Kamasak, and Bulutlar (2009) emphasized that knowledge donating did not have any impact on innovation. Similarly, Lin (2007) found a significant positive relationship between ICT use and knowledge collecting, but no significant relationship with knowledge donating. These different findings revealed that knowledge collecting and knowledge processing were two distinct types of knowledge sharing processes that have a different and separated effect in research literature.

Previous studies revealed that knowledge sharing significantly improve individual innovation, absorptive capacity, and innovativeness (Yesil \& Hirlak, 2013; Hau, Kim, Lee \& Kim, 2013). The success of knowledge sharing process relies on employees who are actively sharing their knowledge. In the service context, the employee who engages in knowledge sharing activity are willingly to share more information (e.g., customer needs, market trend) to their colleagues. Astonishingly, a person who share information are also collect information from counterparts simultaneously. Another attributing factor that drives knowledge sharing behavior is individual perceptions of social interaction within the organization (Intezari, Pauleen, and Taskin, 2017). Positive perceptions lead to better sharing acts compared to the negative one. In addition, the closeness of relationships between individuals, beliefs, friendship relationships, and informal communication patterns are factors that encourage individuals to share knowledge (Janet and Alton, 2013). On the base of above literature and arguments, we proposed hypothesis:

H4: Knowledge donating have a positive relationship on the innovative service behavior.

H5: Knowledge collecting have a positive relationship on the innovative service behavior.

H6: Knowledge donating mediates the relationship between workplace friendship and innovative service behavior.

H7: Knowledge collecting mediates the relationship between workplace friendship and innovative service behavior.

\section{Methodology}

\subsection{Sample and Procedure}

The participant of the study were frontline employees of hotels located in Yogyakarta, one of the provinces with the most significant growth of creative industries and tourism in Indonesia. The targeted hotels were located in the vicinity of well-known tourist destinations in the area including Parangtritis, Malioboro and Keraton. Respondents were limited to frontline workers of the hotels that deal directly with customers in their jobs. Thus, included participants were those in the front office, in charge of room services, as well as serving food and beverages to the hotel guests. Before data collection, the research team initially contact the HR managers in each hotel for permit. Out of fifteen hotels invited to participate in the survey, three refused to take part due to their confidential policy. Self-administered questionnaires were distributed to frontline employees via the hotels' human resource managers. To ensure valid response, the researchers briefs the hotel managers on the content of the questionnaires beforehand. Then, the frontline employees filled in the self-administered questionnaire immediately under the manager's supervision. The length of the data collection was approximately three months starting from March until June 2019.

According to the above explanation, this study investigated the empirical model as follows: 


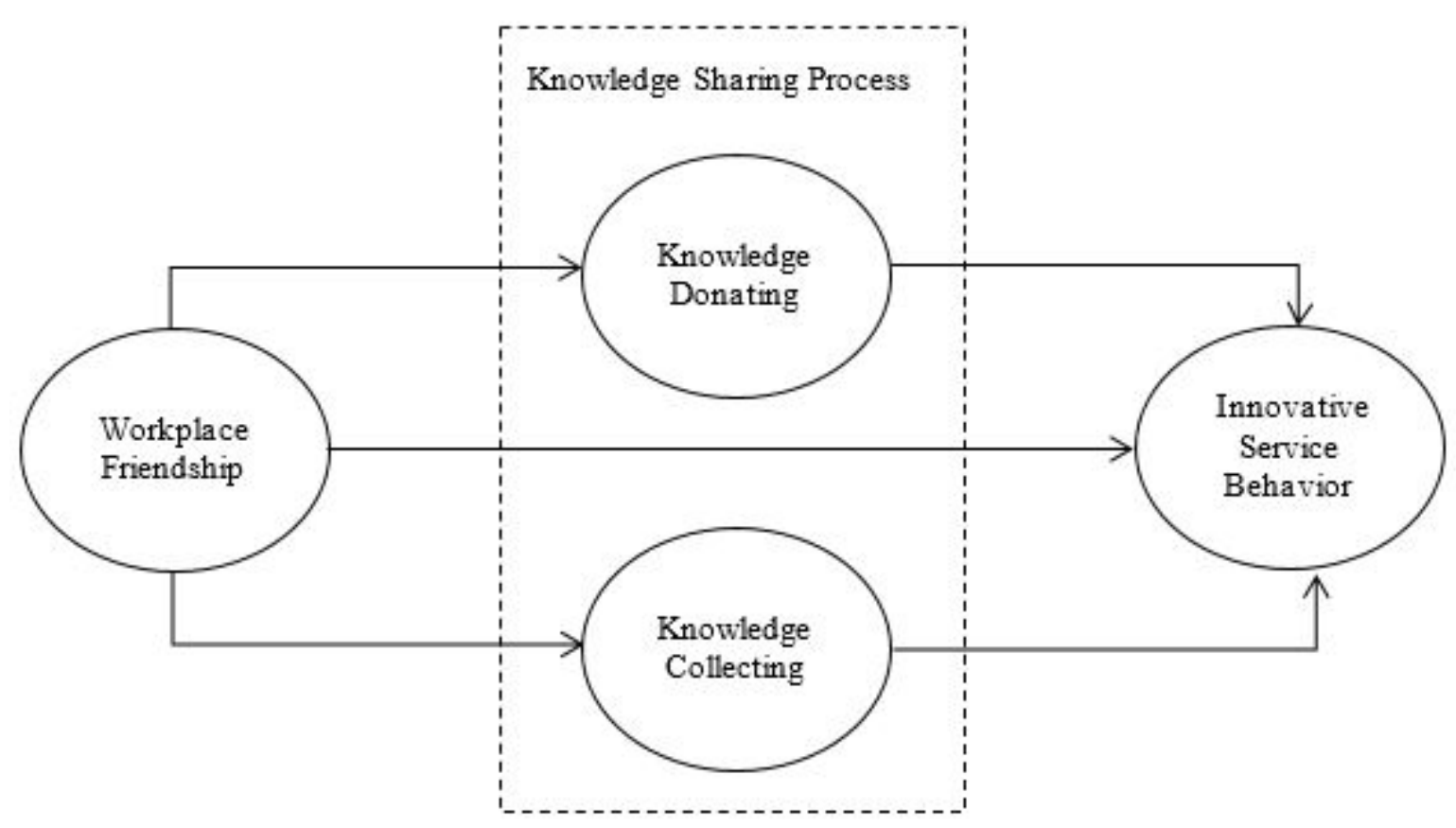

Figure 1: Research Model

This study utilized a convenience sampling method. This design was employed because not all tourist hotels provided access to the survey. Moreover, frontline employees are working in different shifts and different days that hinder the possibility of involving every employee in the study. Convenient sampling is among the least chosen method due to its deficiency in support studies that seek to generalize the findings. To resolve the deficiency, Landers $\&$ Behrend (2015) proposed that the feature of the sample and the setting of the study should be provided. In view of this, we have provided the demographic data of the respondents described as Table 1 .

\subsection{Measurement and Analyses Approach}

This present study employed self-reported questionnaire to measure each variable. All of the survey items were translated from English into Indonesian language using a method of forwarding and backward translation (Brislin, 1970). The measurement of innovative service behavior (six items) was a contextualized version of Luoh, Tsaur, $\&$ Tang (2014). Workplace friendship was measured using a workplace prevalence instrument (six items) developed by Nielsen, Jex \& Adam (2000). Knowledge sharing process measurement in this research was used two-dimensional developed by Van Den Hooff and De Ridder (2004); knowledge donating (three items), and knowledge Collect- ing (four items) (see table 2). All items were rated from 1 (strongly disagree) to 5 (strongly agree). This research used Smart PLS to analyze of the hypotheses and testing of the proposed model. Smart PLS was employed because of it provide support for research with relatively small samples. Moreover, Smart PLS is appropriate to build causal modeling for future testing purposes (Hair et al. 2017).

\section{Results}

\subsection{Demographic Characteristics}

The questionnaires were distributed and collected from 225 employees, and 163 were completed and adequately filled. Thus, the usable response for this study was $72,4 \%$. The demographic data of the respondents are presented in Table 1.

As indicated in Table 1, out of 163 respondents, 97 respondents equivalent to $58.90 \%$ were males. The majority of the respondents $(59.1 \%)$ were secondary and high school graduates while $15.34 \%$ were vocational school holders and $25.15 \%$ were possessed bachelor's degree. Most of the respondents (38.65\%) worked as room service employees and $38.13 \%$ were at the food and beverage department. According to job tenure, most of the respondents $(30.06 \%)$ had work experience between $12-15$ years. 


\subsection{Measurement Model Evaluation}

All minimum requirements are fit with the measurement model, as illustrated in Table 2. First, this study used a cutoff value of 0.70 significance for the loading factor of all items above 0.70 . Higher levels of outside loading factors indicate a higher level of indicator reliability (Hair et al. 2017). Second, all extracted mean values (AVE) exceed the 0.50 threshold, supporting the convergent validity of the construct steps. Composite reliability (CR) precisely explains the convergence and internal consistency of the developed measures. CR estimates the degree to which the respective indicators signal the latent construct. The CR estimates of the latent variables of the present study ranged from 0.859 to 0.925 (Table 2), which exceeded the cut-off value of 0.7 .Third step, to asses discriminant validity, we examined by comparing of the square root of the AVE to each variable relation (Fornell \& Larcker, 1981). The result showed that discriminant validity is established between two constructs association among indicators and greater than that between a construct and any other construct (Hair et al. 2012). Cronbach's alpha coefficients for the multiple-item workplace friendship, knowledge donating, knowledge collecting, and innovative service behavior were $0.807,0.892,0.793$, and 0.876 , respectively, indicating an acceptable level of reliability.

Table 1: Characteristics of respondents $(n=163)$

\begin{tabular}{|l|r|r|}
\hline Demographic Characteristic & Frequency & Percentage \\
\hline Gender & & \\
\hline Male & 96 & $58.90 \%$ \\
\hline Female & 67 & $41.10 \%$ \\
\hline Total & 163 & \\
\hline Education & & \\
\hline Secondary and High School & 97 & $59.51 \%$ \\
\hline Vocational school & 25 & $15.34 \%$ \\
\hline University & 41 & $25.15 \%$ \\
\hline Total & 163 & \\
\hline Hotel Department & & \\
\hline Food and Beverage & 56 & $34.36 \%$ \\
\hline Room service & 63 & $38.65 \%$ \\
\hline Frontdesk & 44 & $26.99 \%$ \\
\hline Total & 163 & \\
\hline Job Tenure (year) & & \\
\hline Under 3 & 3 & $1.84 \%$ \\
\hline $3-5$ & 24 & $14.72 \%$ \\
\hline $6-9$ & 32 & $19.63 \%$ \\
\hline $9-12$ & 40 & $24.54 \%$ \\
\hline $12-15$ & 49 & $30.06 \%$ \\
\hline above 15 & 15 & $9.20 \%$ \\
\hline Total & & \\
\hline
\end{tabular}


Table 2: Convergent, Divergent validity, and Reliability

\begin{tabular}{|l|c|c|c|c|c|c|c|}
\hline \multicolumn{1}{|c|}{ Instrument } & \multirow{2}{*}{ CA } & \multirow{2}{*}{ CR } & \multirow{2}{*}{ AVE } & \multicolumn{5}{c|}{ Instrument } \\
\cline { 5 - 9 } & & & & 1 & 2 & 3 & 4 \\
\hline Workplace friendship (1) & 0.807 & 0.859 & 0.695 & $\mathbf{0 , 8 3 4}$ & & & \\
\hline Knowledge donating (2) & 0.892 & 0.925 & 0.755 & 0.603 & $\mathbf{0 , 8 6 9}$ & & \\
\hline Knowledge collecting (3) & 0,793 & 0.864 & 0.701 & 0.764 & 0.486 & $\mathbf{0 , 8 3 7}$ & \\
\hline Innovative service behavior (4) & 0,876 & 0.890 & 0.715 & 0.558 & 0.108 & 0.442 & $\mathbf{0 , 8 4 6}$ \\
\hline
\end{tabular}

Note: CR, composite reliability; AVE, average variance extracted; CA, cCronbach's alpha; Values above the diagonal in bold are squared inter-construct correlations for Fornell-Larcker criterion.

Table 3: Measurement Model Evaluation Result

\begin{tabular}{|c|c|c|c|c|c|}
\hline Factor & & Measurement Item & Mean & $\begin{array}{l}\text { Standard Devi- } \\
\text { ation }\end{array}$ & $\begin{array}{l}\text { Factor Load- } \\
\quad \text { ing }\end{array}$ \\
\hline \multirow{6}{*}{$\begin{array}{l}\text { Workplace } \\
\text { Friendship }\end{array}$} & WF.1 & I have formed strong friendships at work. & 3.84 & 0.52 & 0.715 \\
\hline & WF.2 & $\begin{array}{l}\text { I socialize with coworkers outside of the } \\
\text { workplace. }\end{array}$ & 3.80 & 0.66 & 0.738 \\
\hline & WF.3 & I can confide in people at work. & 3.85 & 0.58 & 0.769 \\
\hline & WF.4 & $\begin{array}{l}\text { I feel I can trust many coworkers a great } \\
\text { deal. }\end{array}$ & 3.35 & 0.87 & 0.771 \\
\hline & WF.5 & $\begin{array}{l}\text { Being able to see my coworkers is one } \\
\text { reason why I look forward to my job. }\end{array}$ & 3.45 & 1.16 & 0.724 \\
\hline & WF.6 & $\begin{array}{l}\text { I do not feel that anyone I work with is a } \\
\text { true friend. (R) }\end{array}$ & 3.45 & 1.01 & 0.735 \\
\hline \multirow[t]{4}{*}{$\begin{array}{l}\text { Knowledge } \\
\text { Donating }\end{array}$} & KD.1 & $\begin{array}{l}\text { When I've learned something new, I tell } \\
\text { my colleagues about it. }\end{array}$ & 3.47 & 0.71 & 0.879 \\
\hline & KD. 2 & $\begin{array}{l}\text { I share information I have with my } \\
\text { colleagues. }\end{array}$ & 3.55 & 0.84 & 0.860 \\
\hline & KD.3 & $\begin{array}{l}\text { I think it is important that my colleagues } \\
\text { know what I am doing. }\end{array}$ & 3.32 & 0.99 & 0.876 \\
\hline & KD.4 & $\begin{array}{l}\text { I regularly tell my colleagues what I am } \\
\text { doing. }\end{array}$ & 3.25 & 0.98 & 0.861 \\
\hline \multirow[t]{4}{*}{$\begin{array}{l}\text { Knowledge } \\
\text { Collecting }\end{array}$} & KC.1 & $\begin{array}{l}\text { When I need certain knowledge, I ask } \\
\text { my colleagues about it }\end{array}$ & 3.97 & 0.54 & 0,821 \\
\hline & KC.2 & $\begin{array}{l}\text { I like to be informed of what my col- } \\
\text { leagues know }\end{array}$ & 3.65 & 0.65 & 0,727 \\
\hline & KC.3 & $\begin{array}{l}\text { I ask my colleague about their abilities } \\
\text { when I need to learn something }\end{array}$ & 3.58 & 0.60 & 0,775 \\
\hline & KC. 4 & $\begin{array}{l}\text { When a colleague is good at something, I } \\
\text { ask them to teach me how to do it }\end{array}$ & 3.44 & 0.77 & 0,812 \\
\hline
\end{tabular}


Table 3: Measurement Model Evaluation Result (continues)

\begin{tabular}{|l|l|l|c|c|c|}
\hline \multicolumn{1}{|c|}{ Factor } & & \multicolumn{1}{|c|}{ Measurement Item } & Mean & $\begin{array}{c}\text { Standard Devi- } \\
\text { ation }\end{array}$ & $\begin{array}{c}\text { Factor Load- } \\
\text { ing }\end{array}$ \\
\hline $\begin{array}{l}\text { Innovative Ser- } \\
\text { vice Behavior }\end{array}$ & ISB.1 & $\begin{array}{l}\text { I come up with innovative and creative } \\
\text { notions }\end{array}$ & 3.74 & 0.65 & 0,705 \\
\cline { 2 - 6 } & ISB.2 & $\begin{array}{l}\text { I try to propose my own creative ideas } \\
\text { and convince others }\end{array}$ & 3.45 & 0.70 & 0,826 \\
\cline { 2 - 7 } & ISB.3 & $\begin{array}{l}\text { I seek new service techniques, methods, } \\
\text { or techniques }\end{array}$ & 3.48 & 0.58 & 0,755 \\
\cline { 2 - 7 } & ISB.4 & $\begin{array}{l}\text { I provide a suitable plan for developing } \\
\text { new ideas }\end{array}$ & 3.65 & 0.75 & 0.892 \\
\cline { 2 - 7 } & ISB.5 & $\begin{array}{l}\text { I try to secure the funding and resources } \\
\text { needed to implement innovations }\end{array}$ & 3.28 & 0.86 & 0.813 \\
\cline { 2 - 7 } & ISB.6 & $\begin{array}{l}\text { Overall, I consider my self a creative } \\
\text { member }\end{array}$ & 3.49 & 0.74 & 0.863 \\
\hline
\end{tabular}

Note: WFS, workplace friendship; KD, knowledge donating; KC, knowledge collecting; ISB, innovative service behavior.

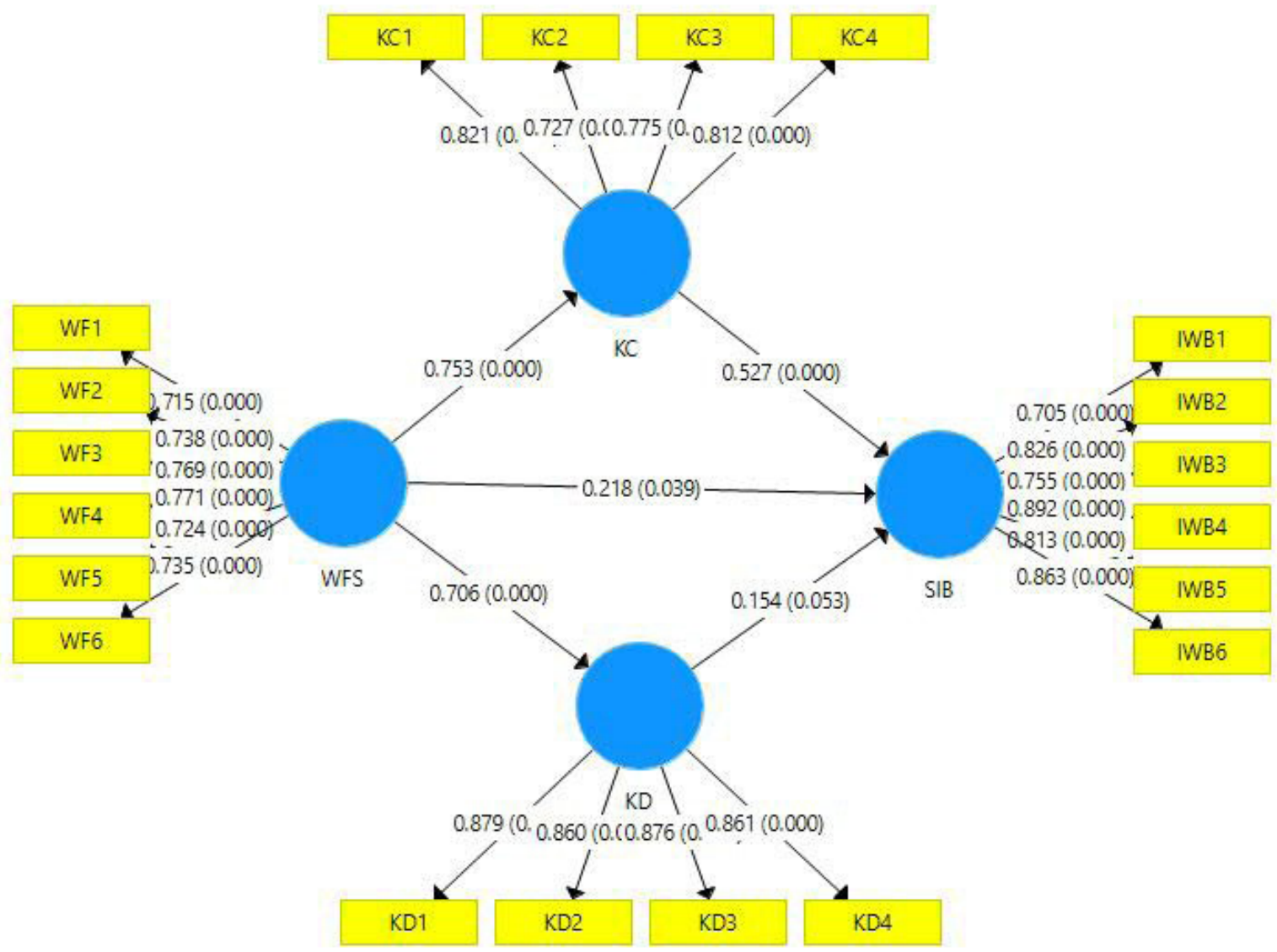

Figure 2: Measurement model 


\subsection{Findings}

For this study, structural equation modelling using a Partial Least Squares (PLS) was used to test the hypotheses. Smart PLS 3 Version 2.0 software was used to perform the analysis.

Table 4 summarizes the results of the best-fit model and explains the direct and indirect relationship between exogenous variables and endogenous variables. In hypotheses $\mathrm{H} 1, \mathrm{H} 2$, and $\mathrm{H} 3$, authors examined the effects of workplace friendship on knowledge donating, knowledge collecting, and innovative service behavior. The results found that workplace friendship had significant effect on ISB ( $\mathrm{t}=2.074 ; \rho=.039)$, knowledge donating ( $\mathrm{t}=16.379$; $\rho<.001)$ and knowledge collecting $(t=16.741 ; \rho<.001)$.
Therefore, H1, H2, and H3 were supported. Furthermore, knowledge collecting was found to positively influence innovative service behavior $(t=5.387 ; \rho<.001)$ and providing support for H5. However, the result also revealed that knowledge donating has no significant relationship with innovative service behavior $(\mathrm{t}=1.941 ; \rho=.053)$. Thus, $\mathrm{H} 4$ was unsupported. Next, according to specific indirect effect test (Hair et al. 2017), this result showed that knowledge collecting partially mediate the relationship between workplace friendship and innovative service behavior $(\mathrm{t}=1.826 ; \rho=.068)$, providing support for H7. On the other hand, the mediating effect of knowledge donating was not significant $(t=1.826 ; \rho=.068)$. Consequently, H6 was not supported.

Table 4: Structural Equation Model Assessment

\begin{tabular}{|l|l|l|l|l|l|}
\hline Variable & $\begin{array}{l}\text { Original } \\
\text { Samples }\end{array}$ & STDEV & $t$-Statistics & $\rho$-Values & Hypothesis \\
\hline WFS $\rightarrow$ ISB & 0.218 & 0.105 & 2.074 & $0.039^{*}$ & H1: Supported \\
\hline WFS $\rightarrow$ KD & 0.706 & 0.043 & 16.379 & $0.000^{* *}$ & H2: Supported \\
\hline WFS $\rightarrow$ KC & 0.753 & 0.045 & 16.741 & $0.000^{* *}$ & H3: Supported \\
\hline KD $\rightarrow$ ISB & 0.154 & 0.079 & 1.941 & 0.053 & H4: Unsupported \\
\hline KC $\rightarrow$ ISB & 0.527 & 0.098 & 5.387 & $0.000^{* *}$ & H5: Supported \\
\hline Specific Indirect Effect & & & & & \\
\hline WFS $\rightarrow$ KD $\rightarrow$ ISB & 0.147 & 0.081 & 1.826 & 0.068 & H6: Unsupported \\
\hline WFS $\rightarrow$ KC $\rightarrow$ ISB & 0.397 & 0.077 & 5.164 & $0.000^{*}$ & H7: Supported \\
\hline
\end{tabular}

Note: $* \rho<.05 ; * * \rho<.001$;

STDEV, standard deviation; WFS, workplace friendship; KD, knowledge donating; KC, knowledge collecting; ISB, innovative service behavior.

\section{Discussion and Implications}

The research findings have confirmed the critical role of friendship relations in shaping service innovation. In this study, workplace friendship found to be the key facilitator in promoting FLEs innovative service behavior. These findings imply that a friendly work environment has an essential role in creating innovation opportunities and develop new services. Workplace friendship was also found a significant influence on both knowledge collecting and knowledge donating. Social capital theory supports our findings that when frontline employees build up friendly relations with others, their willingness to share and collect an idea, information, or method will be stronger. Further, workplace friendship is provide trust and emotional support. Interpersonal trust encourage more effective communication, open discussion and understanding work- related problems. Therefore, workplace friendship motivates frontline employees to work collectively in the problem-solving process. When frontline employees see each other as real friends, they will voluntarily share ideas to find a solution to the problems.

Our study also empirically indicated that knowledge collecting has a mediating effect on the relationship between workplace friendship and FLEs' innovative service behavior. Friendship at work provides opportunities for frontline employees to learn and gather valuable information from coworkers; for example, various customer characteristics and customer complaints on hotel services, which is vital for service encounter innovation. Despite the significant effect of knowledge collecting, this study concluded that knowledge donating was not related to FLEs innovative service behavior. This study is partially in line with previous studies that empirically found knowledge collecting as a better contributor in facilitating the employee innovative work behavior (Akram et al. 2018; Hussein et al. 2016; Kamasak \& Bulutlar, 2009). However, regarding this inconsistent findings, we should not rule out 
the possible impact of inadequate sample size that invariably introduces errors into the final findings (Schoemann, Boulton \& Short, 2017)

This study provides several implications for both hospitality management and theoretical development. First, hotel managers should consider workplace friendship as a rewarding tool for increasing FLEs> innovative service behavior. Hence, as a way of improving workplace friendship, the manager ought to provide an opportunity for employees to socialize with others in a more pleasant environment, for example, comfortable face to face meetings and informal briefing before starting up their work. Furthermore, hotel managers should consider social activities that improve collective intelligence by strengthen the interpersonal trust and emotional connection among coworkers. Second, it implies that FLEs experiencing good quality workplace friendship are more likely to involve in the knowledge collecting and, in turn, trigger higher innovative service work behavior. Thus, managers should consider the mechanism to accelerate the implementation of knowledge sharing collecting process. For instance, managers ought to develop a flexible and build openness knowledge-sharing climate that enable FLEs to collect informations or experinces and also they can learn service delivery from others. This strategy can enlarge employees' knowledge repository which is critial for idea generating on innovation service process.

The third implication, this study theoretically contributes to the social capital literature by enriching the model that predicts innovative service behavior. This research is among the first that attempt to integrate the association among workplace friendship, knowledge sharing process, and innovative service behavior in hospitality service literature. This study also advances previous research by examining two distinctive dimensions of knowledge sharing (knowledge donating and knowledge donating) related to innovative service behavior. However, we have overlooked to capture possible interaction between knowledge donating and knowledge collecting. Therefore, these findings open the doors for further research to investigate the nature of knowledge sharing process related to innovative service behavior.

\subsection{Conclusion, Limitation and Future Research}

This study concludes the importance of workplace friendship to encourage FLEs' innovative service behavior. Workplace friendship promotes a friendly work environment that becomes a trigger for collective intelligence in knowledge sharing behavior. Workplace friendship also provides favorable interaction among FLEs that positively nurturing innovative service behavior trough the knowledge collecting process. However, this research has sev- eral limitations and suggestions for future research. First, the sample size was relatively small. A larger sample is suggested to provide a more accurate, precise, and comprehensive result. Second, the limitation of this study is related to the use of a convenience sampling method. We suggested a probability sampling method in order to leverage the generalization of findings. Third, it would be interesting to replicate this study in a longitudinal method to understand the cause and effect relationship. In addition, a longitudinal study helps scholars discovering factors to sustain workplace friendship, knowledge sharing, and innovative service behavior relationships. Fourth, this study only focuses on the mediating effect of knowledge donating and knowledge collecting on innovative service behavior. However, we suggest the extensive research to investigate the possible interaction between knowledge donating and knowledge collecting. Fifth, this study only concentrated on frontline employees within the hotel service sector. Future research could extend the investigation to different industries to obtain a broader generalization of the study. Moreover, this research was conducted in Indonesia, a developing country with specific cultural features, future research should reinvestigate this current model in various settings (e.g., European or western countries) to reveal any differences or similarities from the present study.

\section{Literature}

Al-Hawari, M., Bani-Melhem, S. and Shamsudin, F. (2019). Determinants of frontline employee service innovative behavior: The moderating role of co-worker socializing and service climate, Management Research Review, 42(9), 1076-1094. https://doi.org/10.1108/ MRR-07-2018-0266

Akhavan, P., \& Mahdi Hosseini, S. (2016). Social capital, knowledge sharing, and innovation capability: an empirical study of R\&D teams in Iran. Technology Analysis \& Strategic Management, 28(1), 96-113. https:// doi.org/10.1080/09537325.2015.1072622

Akram, T., Lei, S., Haider, M. J., \& Hussain, S. T. (2018). Exploring the impact of knowledge sharing on the innovative work behavior of employees: A study in China. International Business Research, 11(3), 186-194. https://doi.org/10.5539/ibr.v11n3p186

Ardichvili, A., Page, V., \& Wentling, T. (2003). Motivation and barriers to participation in virtual knowledge-sharing communities of practice. Journal of Knowledge Management, 7(1), 64-77. https://doi. org/10.1108/13673270310463626

Benjamin, B. (2016). Listen to Your Employees, Not Just Your Customers. Available at https://hbr.org/2016/08/ listen-to-your-employees-not-just-your-customers

Berman, E. M., West, J. P., \& Richter, Jr, M. N. (2002). Workplace relations: Friendship patterns and consequences (according to managers). Public Administration Re- 
view, 62(2), 217-230. https://doi.org/10.1111/00333352.00172

Boyd, N. G., \& Taylor, R. R. (1998). A developmental approach to the examination of friendship in leader-follower relationships. The Leadership Quarterly, 9(1), 1-25. https://doi.org/10.1016/S1048-9843(98)90040-6

Brachos, D., Kostopoulos, K., Soderquist, K. E., \& Prastacos, G. (2007). Knowledge effectiveness, social context and innovation. Journal of Knowledge Management, 11, (5), 31-44. https://doi. org/10.1108/13673270710819780

Brislin, R. W. (1970). Back-translation for cross-cultural research. Journal of cross-cultural psychology, 1(3), 185 - 216. https://doi.org/10.1177/135910457000100301

Cao, F. and Zhang, H. (2020), Workplace friendship, psychological safety and innovative behavior in China: A moderated-mediation model, Chinese Management Studies, Vol. ahead-of-print No. ahead-of-print. https:// doi.org/10.1108/CMS-09-2019-0334

Chang, H. T., Chou, Y. J., Liou, J. W., \& Tu, Y. T. (2016). The effects of perfectionism on innovative behavior and job burnout: Team workplace friendship as a moderator. Personality and Individual Differences, 96, 260-265. https://doi.org/10.1016/j.paid.2016.02.088

De Jong, J., \& Den Hartog, D. (2010). Measuring innovative work behavior. Creativity and Innovation Management, 19 (1), 23-36. https://doi.org/10.1111/j.14678691.2010.00547.x

Engen, M., \& Magnusson, P. (2015). Exploring the role of front-line employees as innovators. The Service Industries Journal, 35(6), 303-324. https://doi.org/10.10 80/02642069.2015.1003370

Hair, J., Hollingsworth, C., Randolph, A. and Chong, A. (2017). An updated and expanded assessment of PLS-SEM in information systems research. Industrial Management \& Data Systems, 117(3), 442-458. https://doi.org/10.1108/IMDS-04-2016-0130

Hau, Y. S., Kim, B., Lee, H., \& Kim, Y. G. (2013). The effects of individual motivations and social capital on employees' tacit and explicit knowledge sharing intentions. International Journal of Information Management, 33(2), 356-366. https://doi.org/10.1016/j. ijinfomgt.2012.10.009

Helmy, I., Adawiyah, W. R., \& Banani, A. (2019). Linking Psychological Empowerment, Knowledge Sharing, and Employees' Innovative Behavior in SMEs. The Journal of Behavioral Science, 14(2), 66-79. Retrieved from https://so06.tci-thaijo.org/index.php/IJBS/article/ view/172180

Hussein, A., Singh, S., Farouk, S. and Sohal, A. (2016). Knowledge sharing enablers, processes and firm innovation capability, Journal of Workplace Learning, 28(8), 484-495. https://doi.org/10.1108/JWL-05-20160041

Intezari, A., Taskin, N., \& Pauleen, D. J. (2017). Looking beyond knowledge sharing: An integrative approach to knowledge management culture. J. Knowledge Mana- gement, 21(2), 492-515. https://doi.org/10.1108/JKM06-2016-0216

Janet, W.C.N. and Alton, C.Y.K. (2013), The peculiarities of knowledge management processes in SMEs: the case of Singapore, Journal of Knowledge Management, 17(6), 958-972. https://doi.org/10.1108/JKM04-2013-0163

Kamaşak, R. \& Bulutlar, F. (2010), The influence of knowledge sharing on innovation, European Business Review, 22(3), 306-317. https://doi. org/10.1108/09555341011040994

Kim, T. T., \& Lee, G. (2013). Hospitality employee knowledge-sharing behaviors in the relationship between goal orientations and service innovative behavior. International Journal of Hospitality Management, 34, 324-337. https://doi.org/10.1016/j. ijhm.2013.04.009

Kratzer, J., Leenders, R. T. A., \& Van Engelen, J. M. (2006). Team polarity and creative performance in innovation teams. Creativity and innovation management, 15(1),96-104. https://doi.org/10.1111/j.14678691.2006.00372.x

Liu, H., Shi, J., Liu, Y., \& Sheng, Z. (2013). The moderating role of attachment anxiety on social network site use intensity and social capital. Psychological Reports, 112 (1), 252-265. https://doi.org/10.2466/21.02.17. PR0.112.1.252-265

Liyanage, C., Elhag, T., Ballal, T. and Li, Q. (2009), Knowledge communication and translation - a knowledge transfer model, Journal of Knowledge Management, 13(3), 118-131. https://doi. org/10.1108/13673270910962914

Lu, Jackson \& Hafenbrack, Andrew \& Eastwick, Paul \& Wang, Dan \& Maddux, William \& Galinsky, Adam. (2017). "Going Out" of the box: Close intercultural friendships and romantic relationships spark creativity, workplace innovation, and entrepreneurship. Journal of Applied Psychology. 102(7), 1091-1108 https://doi. org/10.1037/apl0000212

Luoh, H., Tsaur, S. and Tang, Y. (2014), Empowering employees: job standardization and innovative behavior, International Journal of Contemporary Hospitality Management, 26(7), 1100-1117. https://doi. org/10.1108/IJCHM-03-2013-0153

Melton, H. L., \& Hartline, M. D. (2010). Customer and frontline employee influence on new service development performance. Journal of Service Research, 13(4), 411-425. https://doi.org/10.1177/1094670510369378

Michael, L.A.H., Hou, S.-T. \& Fan, H.-L. (2011), Creative Self-Efficacy and Innovative Behavior in a Service Setting: Optimism as a Moderator. The Journal of Creative Behavior, 45, 258-272. https://doi. org/10.1002/j.2162-6057.2011.tb01430.x

Montani, F., Odoardi, C., \& Battistelli, A. (2014). Individual and contextual determinants of innovative work behavior: Proactive goal generation matters. Journal of Occupational and Organizational Psychology, 87(4), 
645-670. https://doi.org/10.1111/joop.12066

Morrison, R. L. (2004). Informal relationships in the workplace : associations with job satisfaction, organisational commitment and turnover intentions. New Zealand Journal of Psychology, 33(3), https://doi. org/10179/1666

Morrison, R. L., \& Cooper-Thomas, H. D. (2016). Friendship among coworkers. The Psychology of Friendship, 123-140. New York: Oxford University Press.

Nahapiet, J., \& Ghoshal, S. (1998). Social capital, intellectual capital, and the organizational advantage. Academy of management review, 23(2), 242-266. https://doi. org/10.5465/amr.1998.533225

Nielsen, I. K., Jex, S. M., \& Adams, G. A. (2000). Development and validation of scores on a two-dimensional workplace friendship scale. Educational and Psychological Measurement, 60(4), 628-643. https://doi. org/10.1177/00131640021970655

Oldenkamp, J. H. (2001). Succesvol overdragen van kennis (Successful knowledge transfer), Utrecht, Netherlands: Lemma.

Ordanini, A., \& Parasuraman, A. (2011). Service innovation viewed through a service-dominant logic lens: a conceptual framework and empirical analysis. Journal of Service Research, 14(1), 3-23. https://doi. org/10.1177/1094670510385332

Ozkok, O., Bell, S. J., Singh, J., \& Lim, K. (2019). Frontline knowledge networks in open collaboration models for service innovations. AMS Review, 9 (3), 268-288. https://doi.org/10.1007/s13162-018-00133-5

Paulin, D., \& Suneson, K. (2015). Knowledge transfer, knowledge sharing and knowledge barriers-three blurry terms in KM. Leading Issues in Knowledge Management, 2 (2), 73-94. Unique Identifier: 2012-18129007

Pillemer, J., \& Rothbard, N. P. (2018). Friends without benefits: Understanding the dark sides of workplace friendship. Academy of Management Review, 43 (4), 635-660. https://doi.org/10.5465/amr.2016.0309

Riordan, C. M., \& Griffeth, R. W. (1995). The opportunity for friendship in the workplace: An underexplored construct. Journal of Business and psychology, 10 (2), 141-154. https://doi.org/10.1007/BF02249575

Santos-Vijande, M. L., López-Sánchez, J. Á., \& Rudd, J. (2016). Frontline employees' collaboration in industrial service innovation: routes of co-creation's effects on new service performance. Journal of the Academy of Marketing Science, 44(3), 350-375. https://doi.org/10.1007/s11747-015-0447-4

Schoemann, A. M., Boulton, A. J., \& Short, S. D. (2017). Determining power and sample size for simple and complex mediation models. Social Psychological and Personality Science, 8(4), 379-386. https://doi. org/10.1177/1948550617715068

Scott, S. G., \& Bruce, R. A. (1994). Determinants of innovative behavior: A path model of individual innovation in the workplace. Academy of Management Journal,
37 (3), 580-607. https://doi.org/10.5465/256701

Sias, P. M., \& Cahill, D. J. (1998). From coworkers to friends: The development of peer friendships in the workplace. Western Journal of Communication (includes Communication Reports, 62(3), 273-299. https:// doi.org/10.1080/10570319809374611

Sias, P. M., Heath, R. G., Perry, T., Silva, D., \& Fix, B. (2004). Narratives of workplace friendship deterioration. Journal of Social and Personal Relationships, 21(3), 321340. https://doi.org/10.1177/0265407504042835

Song, S. H., \& Olshfski, D. (2008). Friends at work: A comparative study of work attitudes in Seoul city government and New Jersey state government. Administration \& Society, 40(2), 147-169. https://doi. org/10.1177/0095399707312827

Tangaraja, G., Mohd Rasdi, R., Abu Samah, B., \& Ismail, M. (2016). Knowledge sharing is knowledge transfer: a misconception in the literature. Journal of Knowledge Management, 20(4), 653-670. https://doi.org/10.1108/ JKM-11-2015-0427

Van den Hooff, B. and de Ridder, J. (2004), «Knowledge sharing in context: the influence of organizational commitment, communication climate and CMC use on knowledge sharing", Journal of Knowledge Management, 8 (6), 117-130. https://doi. org/10.1108/13673270410567675

Wah, C. Y., Menkhoff, T., Loh, B., \& Evers, H. D. (2007). Social capital and knowledge sharing in knowledge-based organizations: An empirical study. International Journal of Knowledge Management (IJKM), 3(1), 29-48. https://doi.org/10.4018/jkm.2007010103

Weerakoon, C., McMurray, A. J., Rametse, N. M., \& Arenius, P. M. (2019). Social capital and innovativeness of social enterprises: opportunity-motivation-ability and knowledge creation as mediators. Knowledge Management Research \& Practice, 1-15. https://doi.org/10.108 $0 / 14778238.2019 .1590138$

Wang, W. T., \& Hou, Y. P. (2015). Motivations of employees' knowledge sharing behaviors: A self-determination perspective. Information and Organization, 25 (1), 1-26. https://doi.org/10.1016/j.infoandorg.2014.11.001

Wu, W. L., Lin, C. H., Hsu, B. F., \& Yeh, R. S. (2009). Interpersonal trust and knowledge sharing: Moderating effects of individual altruism and a social interaction environment. Social Behavior and Personality: an international journal, 37(1), 83-93. https://doi. org/10.2224/sbp.2009.37.1.83

Wynen, J., Boon, J., Kleizen, B., \& Verhoest, K. (2019). How multiple organizational changes shape managerial support for innovative work behavior: Evidence from the Australian Public Service. Review of Public Personnel Administration, 10(2), 491-515. https://doi. org/10.1177/0734371X18824388

Yeșil, S., \& Hırlak, B. (2013). An empirical investigation into the influence of knowledge sharing barriers on knowledge sharing and individual innovation behavior. International Journal of Knowledge Mana- 
gement (IJKM), 9(2), 38-61. https://doi.org/10.4018/ jkm.2013040103

Yidong, T., \& Xinxin, L. (2013). How ethical leadership influence employees' innovative work behavior: A perspective of intrinsic motivation. Journal of business ethics, 116(2), 441-455. http://dx.doi.org/10.1007/ s10551-012-1509-x

Zarankin, T. G., \& Kunkel, D. (2019). Colleagues and Friends: A Theoretical Framework of Workplace Friendship. Journal of Organizational Psychology, 19(5). https://doi.org/10.33423/jop.v19i5.2517

Zheng, T. (2017). A literature review on knowledge sharing. Open Journal of Social Sciences, 5(3), 51-58. https://doi.org/10.4236/jss.2017.53006

Irfan Helmy is an assistant professor at the Departement of Management, Putra Bangsa Economics College, in Indonesia. He obtained a Doctoral Scholarship Program from The Indonesian Ministry of Research, Technology, and Higher Education (Ristekdikti). Currently, he is completing the dissertation about innovation in Indonesian small and medium enterprises. His research interest mainly focuses on organizational behavior, human resource management, and smallmedium enterprises.
Wiwiek Rabiatul Adawiyah is a professor at the Department of Management, Faculty of Economics and Business, Universitas Jenderal Soedirman, Indonesia. Her research interest is focused on human resource management, entrepreneurship, quality management, and Islamic banking. She is currently appointed as a reviewer in some nationally accredited journals and some reputable international journals. She also actively written scientific articles, textbooks, and conducts international conferences as a keynote speaker.

Harini Abrilia Setyawati is an assistant professor at the Departement of Management, Putra Bangsa Economics College. Currently. She holds a Ph.D. candidate from Jenderal Soedirman University. Her research is focused on the areas of strategic management, marketing and consumer behavior. By collaborating with other researchers, she has published research papers in domestic and international journals. 